\title{
Sustainability Aspects of Facilities Management Companies
}

\author{
Alan K. Millin ${ }^{1}$ \\ ${ }^{1}$ Business School, University of Cumbria, Ambleside, England, UK \\ Correspondence: Alan K. Millin. P. O. Box 126305, Dubai, United Arab Emirates. Tel: 971-50-5945-700. E-mail: \\ akmillin@hvacandr.com
}

Received: January 16, 2014 Accepted: February 20, 2014 Online Published: May 27, 2014

doi:10.5539/jms.v4n2p12 URL: http://dx.doi.org/10.5539/jms.v4n2p12

\begin{abstract}
Purpose: In a fiercely competitive post-recession business climate facilities management companies have to do more than deliver sustainable services to clients, they also have to stay in business and prosper. There is a need for relevant business sustainability aspects to be identified and documented. This paper meets that need.

A literature review, followed by an online survey was used. FM practitioners within the Gulf Cooperation Council region were asked about their companies' adoption of sustainability related practices.

The research has enabled the identification of key sustainability aspects that should be considered by FM leadership teams. Primary research reveals that within the GCC FM community business leaders are failing to identify risk to their businesses while useful guidance in the form of published standards is largely ignored. Sustainability maturity among these companies is generally low. A taxonomy of sustainability aspects is introduced which may be used to guide and support FM companies towards sustainability maturity and also provide the foundation for year-on-year performance improvement.

Primary research was only conducted within the Gulf Cooperation Council region. Future research should consider the wider FM community. A suite of performance indicators for the identified sustainability aspects should be developed.
\end{abstract}

Keywords: facilities management, facility management, sustainability, corporate responsibility, fm, risk

\section{Introduction: The Call to Sustainability Action}

The recent global financial crisis and resulting recession left many businesses facing a crisis. At the end of March 2009 for instance, US companies had faced the worst rolling10-year period since 1834 (Staton \& Staton, 2010). In the Gulf Cooperation Council (GCC) countries of Bahrain, Kuwait, Oman, Qatar, Saudi Arabia and the United Arab Emirates (UAE), the financial turmoil also left many businesses facing serious issues, particularly in the construction industry.

The UAE's growth rate in the years before the global financial crisis was shown to be unsustainable, fuelled as it was by construction projects and rising real estate prices (BMI, 2012).

The employment regulations in GCC countries require expatriate employees to be on a company visa to be able to live and work in the Gulf Countries (PRS, 2011). If an individual is made redundant the person will then have to either find another employer or leave the country.

As construction projects were delayed or cancelled, many expatriates lost their jobs and, consequently, their residence visas, forcing large numbers of workers to return to their homelands. One outcome of the recession was therefore an oversupply of property (BMI, 2012). While the UAE was perhaps the worst affected of the GCC countries, the other GCC member states also have large expatriate populations.

The sudden reduction in construction activity lead to a significant reduction in the number of new properties entering the real estate market and this had a knock-on effect on service industries such as facilities management.

An oversupply of buildings, down-sized pool of skilled labour, along with falling rents and associated facility service charges, all challenged the sustainability of FM provider business models, as facility owners and end-users demanded more for less.

FM providers routinely strive to reduce facility operating costs for their clients in order to support the clients' business demands. There is therefore a considerable focus on delivering sustainable services and solutions. 
The most recent FM growth years in the GCC were fuelled by the construction boom in Dubai, United Arab Emirates. With the introduction of regulations allowing freehold ownership of properties by expatriates in Dubai, issues of jointly owned properties (JOPs) were dealt with by the Dubai Real Estate Regulatory Authority (RERA). RERA mandated that JOPs be managed by owners' associations (RERA, 2012). This mandate generated a market for owners' association management companies which are bound to provide the best value for the associations they serve. As a result, price has become a more heavily weighted criterion in the FM contract award process which is driving the commoditization of FM. The commoditization process in turn puts pressure on the profits of FM providers and makes the consideration of sustainable business practises more urgent.

The post-recession situation finds FM companies competing in an increasingly competitive market.

\section{Research Aims}

The aim of this research is to identify aspects of sustainability important to FM companies and to develop a taxonomy of those aspects.

The taxonomy will provide a basis for the creation of a single sustainability index.

FM companies may then develop performance indicators as inputs to the index to both monitor and drive sustainability maturity.

\section{Literature Review}

Delivering customer satisfaction is essential for the survival of an FM company (Sweeney, 1996).

The need for the delivery of sustainable FM is recognized by Langston and Ding (2001). The focus of Langston and Ding's work is however on achieving sustainability within the built environment. The authors devote a final chapter to facilities management and FM-related sustainability considerations but, while the chapter sub-topics may be relevant to sustaining the internal business, they do not directly focus attention on the sustainability of the actual FM provider company. Langston and Ding do discuss the measurement of sustainability and propose a sustainability index that may be used to assess projects in the built environment.

New tools are needed to enable FM to develop sustainably (Hudson, 2004). Hudson also notes the concept of the "Triple Bottom Line" approach of economic, social and environmental bottom lines, developed specifically for businesses as an alternative to the use of sustainability indicators. The author also warns that any tools used for FM should be used with conviction rather just to pay lip-service to sustainability.

Barrett and Baldry (2003) focus their efforts on the delivery of FM services. These authors also include topics that may be relevant to the sustainability of FM businesses, such as improving FM performance, procurement and managing people. The information provided is geared very much to service delivery rather than to business administration.

Dehning and Stratopoulos (2003) found that successful implementers of IT who gain peer recognition may establish a competitive advantage but that the advantage may be short-lived unless supported by management expertise and protected from the competition. Calder and Watkins (2004) inform us that all organizations own information that is either business-critical or sensitive. Loss of such data could have serious implications for the sustainability of an FM company. Implementation of an information management security system (ISMS) by FM companies would therefore support the sustainability of any competitive advantage obtained through the innovative use of ICT systems.

Shah (2007) goes much further than Langston and Ding. The author dedicates one of the four sections of his work to sustainable business management. Shah identifies fourteen sustainability categories for consideration by facility managers and also introduces what he describes as "the 'ideal' position for business functions to support sustainable development". Shah's ideal position includes a sales and marketing business function but this function is not explored or expanded upon throughout the book. Shah also places emphasis on "greening" the supply chain and lists several benefits of doing so, including reputation and brand equity. Shah (2007) leans heavily on the concept of corporate responsibility to deliver business benefits and includes a corporate responsibility roadmap matrix which can be used as an assessment tool. He does not include a method for assessing the sustainability of a business. Matrix models such as that introduced by Shah and the Sustainable Development Maturity Matrix included in BSI (2006) are open to considerable interpretation.

Referring to green marketing, Grant (2008) suggests three levels of "greening"; Green, Greener and Greenest, with Greenest "making new ways of life and new business models normal and acceptable". Belz and Peattie (2009) also positively promote strategic sustainable marketing. The authors argue that this discipline provides the tools needed to convert sustainability marketing values into commercially beneficial results. 
Booty (2009) includes a section on "managing your business effectively" and includes valuable information on topics such as finance, risk management, costs, information security and business continuity. The author provides a section on sustainable property but does not provide any system or recommendation for monitoring the performance of an FM company from a sustainability perspective. Similarly, Payant and Lewis (2007) discuss business continuity, under the banner of emergency preparedness, along with capital investment and lifecycle costing but they do not turn their focus to internal business sustainability.

Theriault (2010) introduces eleven core FM competencies as identified by the International Facility Management Association (IFMA). These include Environmental Stewardship and Sustainability, Finance and Business and Human Factors, all of which can impact the sustainability of an FM business.

The planning of FM service provision should be linked to the organization's strategic plan (Teicholz, 2001). Teicholz describes the relationship of FM to the corporate business strategy but does not suggest a method of quantifying a company's performance or progress toward sustainability.

Wiggins (2010), in her list of factors influencing the development of FM, includes sustainable development and, like Shah (2007), corporate responsibility. The author also notes that FM will develop as a result of pressure from environmentalists and legislation, suggesting that FM is a reactive discipline rather than one that seeks to lead the way to sustainability. Wiggins does not suggest the use of any sustainability metric or index to assess and report the sustainability of FM companies. In a similar manner to Teicholz (2001), Wiggins discusses several aspects of FM that may affect the sustainability of FM providers but does not explore the subject directly.

O'Neill (2010) advocates the development of a "Green IT" policy as a component of sustainable business practice. The author promotes the use of information technology (IT) in facilities to help conserve energy, a particular focus of many FM companies. O'Neill also discusses waste management, another key FM service, under Green IT.

A strategy for sustainability is essential for the survival of a business (Werbach, 2009). Werbach also warns that if a company has no sustainability strategy, its existing strategy is already outdated.

\subsection{Performance Measurement}

BSI (2006) provides a sustainability maturity matrix as a tool to allow companies to establish their current sustainability position and chart a path to greater maturity. The matrix however introduces a considerable level of subjective interpretation into an assessment of maturity, referring to criteria such as "some dialogue with immediate stakeholders", "compliance to (one or more) public codes" and "selective to determined ends". The authors do however recommend that an organization identifies its sustainability objectives and then identify key indicators that directly support those objectives. Methods should then be defined to enable these indicators to be used to assess performance.

Hitchcock and Willard (2009) promote the development of a sustainability management system to support a company's drive for sustainability. The authors introduce the SCORE system, using a matrix in similar fashion to BSI (2006) and then invite the reader to allocate points to each line of the matrix. Individual line scores are then totalled and averaged to obtain a final sustainability score. A key is provided to interpret the resulting score. The range of scores permitted also invites a level of subjectivity while some of the suggested parameters for assessing a service company, such as offering incentives to contractors and customers to reduce fossil fuel use, may have adverse impacts on the FM company's financial bottom line if not mitigated.

Simply offering incentives for others to reduce fossil fuel use does not automatically translate to increased sustainability of the company providing the incentives. The authors also include achieving LEED ${ }^{\circledR}$ (Leadership in Energy and Environmental Design) certification for the company's facilities. LEED ${ }^{\circledR}$ is a green building rating system but achieving LEED ${ }^{\circ}$ certification of a facility does not necessarily mean that a company is operating sustainably. Further, obtaining LEED ${ }^{\circledR}$ certification of a facility is no guarantee that the facility will be operated sustainably (Roudman, 2013).

In similar fashion, an FM company having an environmental policy does not automatically mean that environmental and sustainability practices are implemented internally (Price \& Pitt, 2011). Price and Pitt also confirm that there is a minimal amount of research in the area of FM company sustainability policies and that the existence of a sustainability policy does not mean that the organization is communicating sustainability related information throughout the company.

More recently, Meng and Minogue (2011) conducted a comparative study of performance measurement models in FM, focusing on organizations in the UK and Ireland. The authors concluded that the Balanced Scorecard (BSC), Business Excellence Model (BEM) and Key Performance Indicators (KPI) are more widely used and accepted than other systems. 
The authors note the shortcomings of BSC when applied to FM and inform us that the BSC model has been extended beyond its four core perspectives of finance, customer, internal business process and learning growth. This extension has however focused externally, with application on the performance of government facilities rather than on core FM business sustainability.

BEM is based on nine criteria and describes a relationship between business enablers and outcomes (Meng \& Minogue, 2011). These nine criteria may be considered as categories, which fall considerably short of the 14 categories identified by (Shah, 2007).

KPI's are in common use throughout FM, most commonly as indicators of service provided rather than indicators of internal business performance. Meng and Minogue (2011) note that KPI's are more commonly used by FM exponents than other methods. KPI's are discrete measures of performance rather than an overall measure and may therefore provide useful input into a more comprehensive sustainability performance metric or index. Meng and Minogue do note in their conclusion the merging of various client satisfaction indicators into a single indicator. This suggests that combining individual indicators or drivers to produce a single sustainability metric that can be used to assess an FM company's sustainability potential and drive continuous improvement is possible.

Reineck et al. (2011) introduce a suite of FM key performance indicators (KPIs) for management processes which the authors recommend for quantifying sustainability in FM through their Return on Sustainability Systems (RoSS) application. The authors have grouped the KPIs into the following dimensions of the Triple Bottom Line:

- Economic

- Environmental

- Social

Reineck et al. (2011) have not considered risk to the very existence of the company and have therefore overlooked the essential sustainability aspects of business continuity planning and risk management. This leaves leadership teams at risk of focusing on business acquisition and service delivery while exposing their organizations to risk of serious disruption or worse due to ICT systems failure, natural disaster etc.

The authors also note that every FM process can be divided into sales, establishment, execution and termination phases and state that sustainability criteria for each phase have been developed. They do not elaborate on these criteria.

\subsection{Business Disruption}

A business may face a serious threat to its operations every four years and many companies will fail within two years of a crisis due to lack of continuity planning (Wiggins, 2010).

Figure 1 shows the reasons for reported business disruption for the period August 2011 to March 2012 (Risk Centric, 2012).

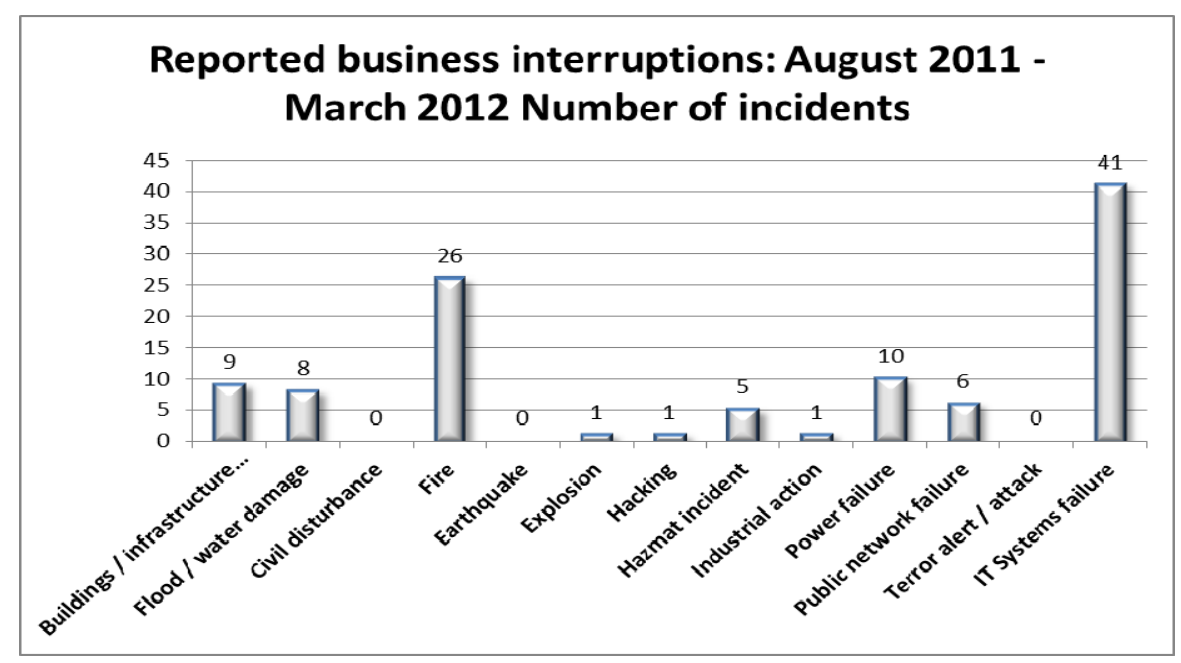

Figure 1. Reported business interruptions (August 2011-March 2012) 
It is evident from Figure 1that information and communication technology (ICT) issues are a major cause of business disruption. Riskcentric gathers and presents data on global business disruption incidents which makes it clear that fire, power outages and ICT present significant risk to business continuity. Calder and Watkins (2004) note that all companies have critical and sensitive data. Figure 1 graphically represents the risk to the availability, security and integrity of that data.

\subsection{Taxonomy of FM Company Sustainability Issues}

Much has been written on the topics of sustainable development, business continuity and facilities management but the literature does not cover the sustainability of facilities management companies specifically to any great depth. The literature reveals several aspects that may be considered as inputs when developing a sustainability model for FM companies and these inputs form the basis for a taxonomy of FM company sustainability issues.

The main sustainability aspects are:

- $\quad$ Fire - (RiskCentric, 2012)

- $\quad$ Power - (RiskCentric, 2012)

- $\quad$ ICT - (RiskCentric, 2012; O'Neill, 2010)

- $\quad$ Emissions to air and water - (Shah, 2007)

- $\quad$ Energy management - (Shah, 2007)

- Waste management - (Shah, 2007)

- Land contamination - (Shah, 2007)

- $\quad$ Environmental \& Community - (Shah, 2007; Theriault, 2010)

- $\quad$ Workforce - (Shah, 2007)

- $\quad$ Lifecycle of products \& services - (Shah, 2007)

- $\quad$ Market place - (Shah, 2007)

- Human rights - (Shah, 2007) / Human factors (Theriault, 2010)

- $\quad$ Biodiversity - (Shah, 2007)

- $\quad$ Transport - (Shah, 2007)

- $\quad$ Corporate responsibility - (Shah, 2007; Wiggins, 2010)

- $\quad$ Risk - (Booty, 2009; (Wiggins, 2010)

- $\quad$ Business continuity - (Payant and Lewis, 2007)

- $\quad$ Sustainability strategy - (Werbach, 2009)

- Health, safety and quality - (Shah, 2007; Reineck et al., 2011)

- Business operations / customer relationship (Reineck et al., 2011)

- Workforce composition / employee retention(Reineck et al., 2011)

These issues are presented as a taxonomy of FM company sustainability issues in Figure 2. 


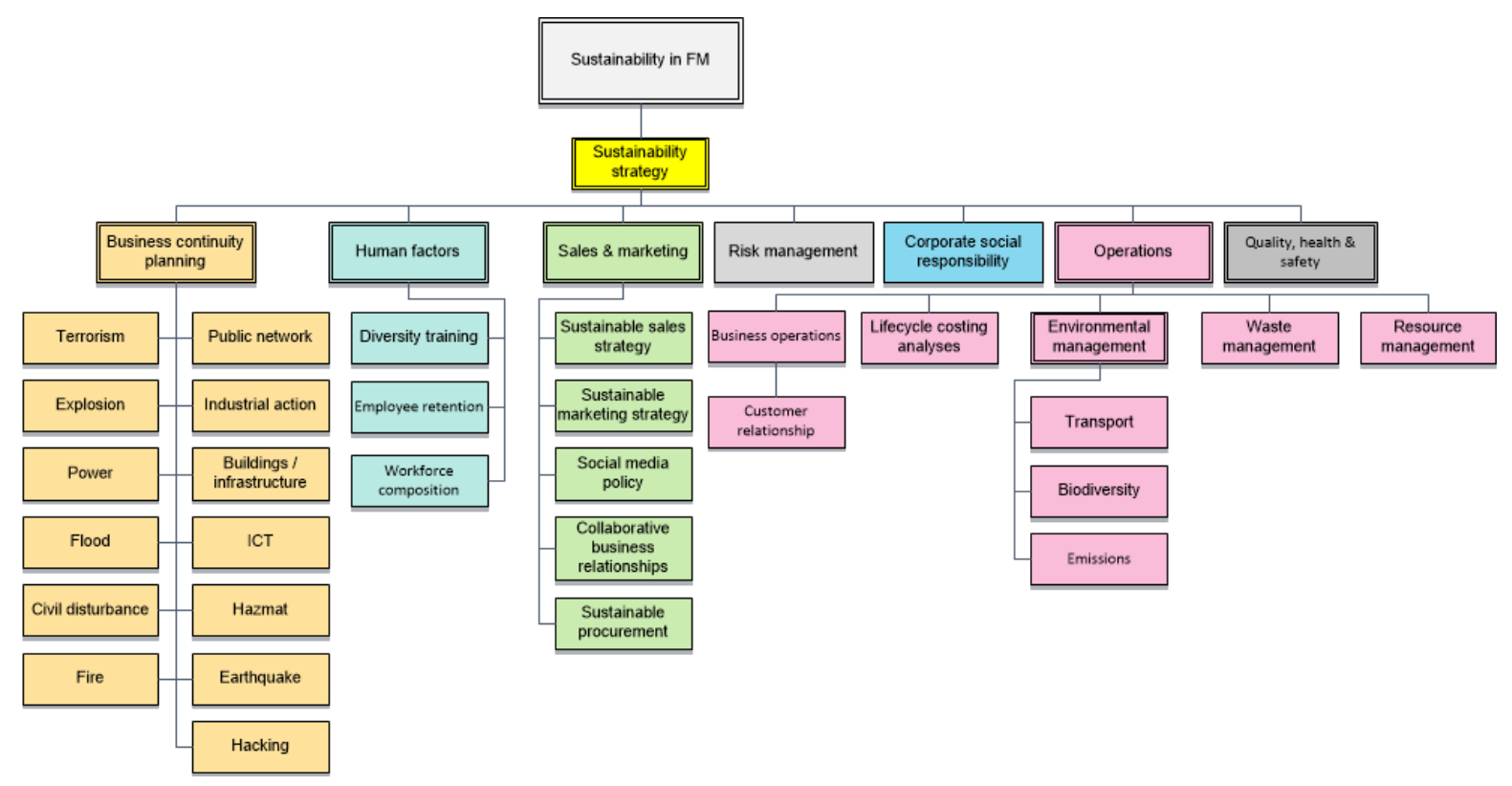

Figure 2. Taxonomy of sustainability aspects

\section{Primary Research}

An online survey was used to gather information related to the sustainability of FM companies within the GCC region. The survey was completed by $57 \mathrm{FM}$ practitioners, however 22 of the responses were considered invalid for one or more of the following reasons:

- Responses were only partial

- Participants did not submit their company name

- Participants provided responses that failed to stand up to simple verification checks

- Participants were from companies that did not operate within the GCC region

Valid responses were received from 35 participants representing 26 FM-related companies within the GCC. It was found that participants from the same company responded to differently to certain questions. These questions asked participants whether their companies trained everyone in the contents of the business continuity plan and social media policy.

The conflicting results suggest either a lack of knowledge, lack of communication or lack of training within the organization concerned.

\subsection{Sustainability Metrics}

7 participants indicated that their companies used a single, numerical sustainability index. Simple verification checks confirmed that 6 of these responses were incorrect. This supports the findings of Price and Pitt (2011), who found that survey participants responded to sustainability questions in a manner that was not reflected at their companies. This type of socially acceptable answering has also been identified by (Bradburn et al., 2004).

One participant response was found to be credible on the use of a numerical sustainability index. The company website supports the participant's comments on all points except the use of a numerical sustainability metric. The respondent indicated that an audited numerical scale was used based on the following parameters:

- Community impact

- Environmental

- Climate change \& energy

- Production and consumption

This company is referred to as "Company X" throughout the remainder of this paper.

A graphical representation of inputs to Company X's sustainability metric, based on the participant's response and information available on the company's web site, is shown in Figure 3. 


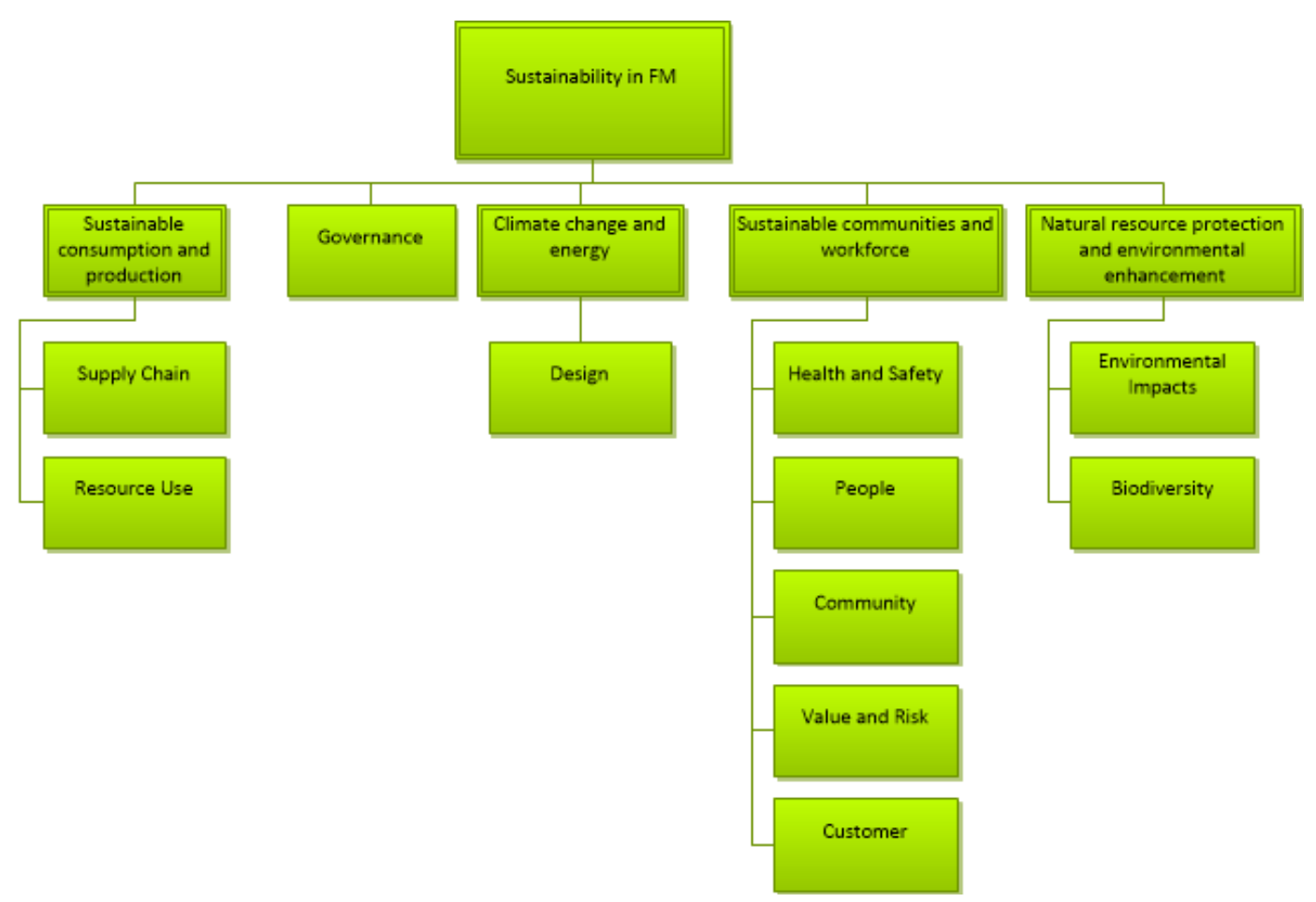

Figure 3. Company $\mathrm{X}$ sustainability aspects

Figure 3 reveals 5 main categories of sustainability driver for Company X's sustainability metric while the taxonomy of sustainability drivers developed as a result of this research shows 7 main categories supporting an overarching sustainability strategy.

Company X has not incorporated the sales and marketing functions identified by Shah (2007) as one of the key components to support sustainable development.

Company $\mathrm{X}$ has also failed to identify the key sustainability aspect of information and communication technology (ICT). RiskCentric (2012), Wiggins (2010) and Panagopoulos and Avlonitis (2010) all highlight the impact of ICT systems on the sustainability of a business. In the taxonomy developed through this research, ICT is categorized as an input to business continuity planning. Only 2 out of 3 Company X participants stated that their company had a business continuity plan (BCP) with the other not knowing. This inconsistency suggests that Company X's business continuity planning is not yet fully developed or optimized.

Company $\mathrm{X}$ uses 10 inputs to its 5 sustainability categories while the taxonomy shown in Figure 2 has 30 inputs to 7 categories.

While Company $\mathrm{X}$ has included people as a sustainability aspect, it has not identified diversity as a specific issue. This is supported by 2 out of 3 participants from this company who responded that Company X does not provide diversity training. The third participant, who was not the same person who provided details of the company's sustainability metric, answered that the company does provide diversity training.

\subsection{Sustainability Strategies}

Werbach (2009) notes that a sustainability strategy is necessary if a company hopes to survive while Panagopoulos and Avlonitis (2010) confirm that a sales strategy developed at the corporate level can have a positive impact on the sales force and company performance. Belz and Peattie (2009) highlight the benefits of sustainable marketing strategies.

Participants from 9 different companies, 6 FM service providers and 3 FM consumers, confirm that their companies have a strategy for sustainability.

\subsection{Collaborative Business Relationships}

Only 3 participants indicated that their companies followed the guidance BSI (2010) to establish collaborative business relationships. 


\subsection{Information Security}

Of the 26 companies represented, only 6, 3 FM service providers and 3 FM consumers implement a standards-based information management security system.

\subsection{Following Guidance to Manage Sustainability}

Only 2 participants, representing $1 \mathrm{FM}$ consumer and $1 \mathrm{FM}$ consultancy, responded that their companies do follow the guidance of BSI (2006), Guidance for managing sustainable development.

A second participant from the same FM consultancy responded that his company did not follow the guidance of BS8900:2006. This lack of consistency implies that the standards-based guidance is not being followed fully within the FM consultancy.

Four of the 26 companies represented in the survey, 2 FM service providers, 1 FM consultancy and 1 FM consumer, responded that their companies follow the guidance of BS 8903:2010-Principles and framework for procuring sustainably.

\subsection{Revised Taxonomy}

As a result of the primary research a revised taxonomy of sustainability aspects for FM companies is introduced as Figure 4 with 2 training aspects added.

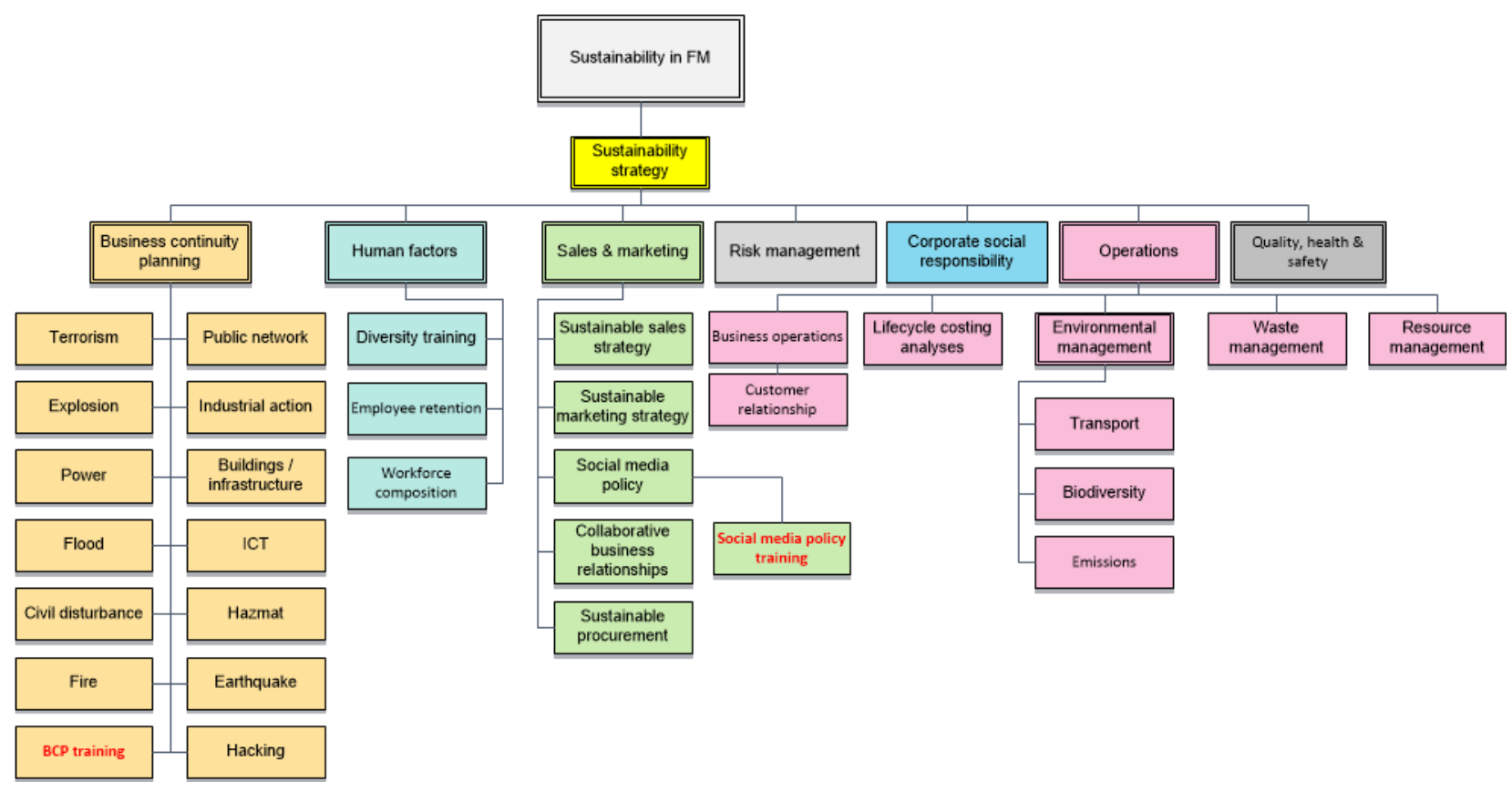

Figure 4. Revised taxonomy of sustainability aspects

FM companies can use this taxonomy to establish relevant performance indicators to monitor and drive sustainability maturity.

\section{Conclusions}

The primary research reflects that of Price and Pitt (2011), who found that some of the answers provided to their survey questions were not representative of actual conditions when they visited companies. This situation led to several survey responses being rejected from further consideration for this research.

Survey responses reveal a lack of consistency from participants of the same organization. This suggests either a lack of knowledge, lack of communication or lack of training within the organization concerned, none of which is good from a sustainable business perspective. There is also the possibility that some of the responses were what participants deemed to be socially acceptable, resulting in inconsistencies.

The research has revealed a lack of appreciation for the implications of diversity within a multicultural workforce. With the GCC countries relying heavily on expatriate labour from around the world an appreciation of diversity 
can enable a company to reap performance benefits (Robbins \& Judge, 2011). Diversity training would therefore introduce the opportunity to unlock and exploit the potential within an FM organization.

Company $\mathrm{X}$ has taken a significant step towards supporting its own sustainability by implementing its audited, numerical sustainability indicator. The indicator can, however, be considerably strengthened to provide a much more comprehensive assessment of the company's sustainability maturity. The taxonomy of key FM sustainability drivers developed as a result of this research provides a foundation for developing this stronger sustainability indicator.

The research indicates that FM companies in the GCC region are failing to exploit the opportunities for business sustainability that can be gained from sustainable sales and marketing strategies that the literature confirms exist.

Rackham et al. (1996) note that beyond transactional relationships, an intimacy develops between partnering companies which leads to "a tremendous source of sustainable competitive advantage". This research reveals that many FM companies in the GCC should therefore be seeking to establish much stronger, more intimate relationships with clients and their supply chain partners to improve performance and support business sustainability. Rackham et al. confirm that collaborative business relationships support sustainable business and also tell us that partnering benefits companies that can move beyond traditional relationships and punishes those that cannot.

The research also reveals that at the GCC regional level, FM companies do not appear to place importance or priority on managing sustainable development and sustainable procurement in a structured, standards-based way and are largely overlooking the significant risk to business presented by the growing reliance on information technology systems.

There is clear room for improvement in the GCC FM profession from a strategic sustainability perspective and the potential for improvement in the sustainability maturity of these FM companies is therefore considerable.

\section{References}

Barrett, P., \& Baldry, D. (2003). Facilities Management—Towards Best Practice. Oxford: Blackwell Publishing. Belz, F. M., \& Peattie, K. (2009). Sustainability Marketing. Chichester: John Wiley \& Sons Ltd.

BMI. (2012). UAE Business Forecast Report Q2 2012. London.

Booty, F. (2009). Facilities Management Handbook. Oxford: Elsevier.

Bradburn, N., Sudman, S., \& Wansink, B. (2004). Asking Questions. San Francisco: Jossey-Bass.

BSI. (2006). BS 8900:2006 Guidance for Managing Sustainable Development. British Standards Institution, London.

BSI. (2010). BS 11000-1:2010 Collaborative business relationships-Part 1: A framework specification. British Standards Institution, London.

Calder, A., \& Watkins, S. (2004). IT Governance. Kogan Page, London.

Dehning, B., \& Stratopoulos, T. (2003). Determinants of a sustainable competitive advantage due to an IT-enabled strategy. The Journal of Strategic Information Systems, 12, 7-28. http://dx.doi.org/10.1016/S0963-8687(02)00035-5

Grant, J. (2008). The Green Marketing Manifesto. Chichester: John Wiley \& Sons Ltd.

Hitchcock, D., \& Willard, M. (2009). The Business Guide to Sustainability—practical strategies and tools for organizations. Earthscan, London.

Hudson, J. (2004). Towards a more sustainable industrial workplace. In Alexander, K., Atkin, B., Bröchner, J., \& Haugen, T. (Eds.), Facilities Management Innovation and Performance (pp. 75-82). Oxon: Spon Press Abingdon.

Langston, C. A., \& Ding, G. K. C. (Eds.) (2001). Sustainable Practices in the Built Environment. Oxford: Butterworth-Heinemann.

Meng, X., \& Minogue, M. (2011). Performance measurement Models in Facility Management: A Comparative Study. Facilities, 29, 472-484. http://dx.doi.org/10.1108/026327711111157141

O'Neill, M. G. (2010). Green IT For Sustainable Business Practice. BISL, Swindon.

Panagopoulos, N. G., \& Avlonitis, G. J. (2010). Performance implications of sales strategy: The moderating effects of leadership and environment. International Journal of Research in Marketing, 27, 46-57. 
http://dx.doi.org/10.1016/j.jiresmar.2009.11.001

Payant, R. P., \& Lewis, B. T. (2007). Facility Manager's Maintenance Handbook. New York: McGraw-Hill.

Price, S., \& Pitt, M. (2011). Implications of a sustainability policy for facilities management organisations. Facilities, 29, 391-410. http://dx.doi.org/10.1108/02632771111146314

PRS. (2011). Country Conditions. Political Risk Yearbook: UAE Country Report, 1-17.

Rackham, N., Friedman, L., \& Ruff, R. (1996). Getting Partnering Right. New York: McGraw-Hill.

Reineck, M., Poltermann, J., May, M., \& Pelzeter, A. (2011). Measuring Corporate Sustainable Development in Facilities Management with Key Performance Indicators. Oida International Journal of Sustainable Development, 2, 69-76.

RERA. (2012). Land Department-Owner's Association Overview. Retrieved from http://www.dubailand.gov.ae/English/Tanzeem/Owners_Association/About_Owners_Association.aspx

RISKCENTRIC. (2012). Thin Ice-The continuous survey of business interruptions. Retrieved from http://www.bifm.org.uk/bifm/knowledge/resources/library/filegrab/q12012.pdf?type=documents\&ref=4559

Robbins, S. P., \& Judge, T. A. (2011). Organizational Behavior. New Jersey: Prentice Hall.

Roudman, S. (2013). Bank of America's Toxic Tower. Retrieved from $\mathrm{http}: / / w w w . n e w r e p u b l i c . c o m / a r t i c l e / 113942 /$ bank-america-tower-and-leed-ratings-racket\#

Shah, S. (2007). Sustainable Practice for the Facilities Manager. Oxford: Blackwell Publishing Ltd. http://dx.doi.org/10.1002/9780470759677

Staton, B., \& Staton, M. (2010). America's Finest Companies 2010. Hoboken, NJ: John WIley\& Sons Inc.

Sweeney, D. B. (1996). Foreword. In K. Alexander (Ed.), Facilities Management Theory and Practice. Oxon: Taylor \& Francis Abingdon.

Teicholz, E. (2001). Facility Design and Management Handbook. McGraw-Hill.

Theriault, M. (2010). Managing Facilities \& Real Estate. Toronto: WoodStone Press.

Werbach, A. (2009). Strategy for Sustainability. Boston: Harvard Business Press.

Wiggins, J. M. (2010). Facilities Manager's Desk Reference. Chichester: Wiley-Blackwell.

\section{Copyrights}

Copyright for this article is retained by the author(s), with first publication rights granted to the journal.

This is an open-access article distributed under the terms and conditions of the Creative Commons Attribution license (http://creativecommons.org/licenses/by/3.0/). 